\title{
Taxation, Dividend Payments and Ex-Day Price-Changes
}

\author{
Sven-Olov Daunfeldt ${ }^{\star}$ \\ The Ratio Institute, Sweden \\ Carina Selander** \\ Umeå University, Sweden \\ Magnus Wikström** \\ Umeå University, Sweden
}

\begin{abstract}
The purpose of the paper is to study the effect of taxation on dividend payments and ex-dividend price-changes in Sweden during 1991-1995. Tax changes in Sweden during the 1990s were implemented in such a way that they provide an opportunity to include direct measures of the tax-treatment of dividends and capital gains in the empirical analysis, in contrast to previous studies. The results indicate that tax-reforms can have large effects on dividend payments, while the effects on ex-dividend price-changes are less conclusive.(JEL: G12, G35)
\end{abstract}

Keywords: censoring, dividend, ex-dividend, taxation.

\section{Introduction}

It has long been noticed that taxes on dividends and capital gains may have important effects on stock prices and corporate dividend-policies. In an influential paper, Elton and Gruber (1970) argued that the price-drop-to-dividend ratio $(D O R)$ on the ex-dividend day is determined by the net-of-marginal-tax ratio between dividends and

\footnotetext{
* The Ratio Institute, P.O. Box 3203, SE-103 64 Stockholm, Sverige (Sweden); and Department of Economics, University of Gävle, SE-804 26, Gävle, Sverige (Sweden). E-mail: sod@hig.se. ${ }^{* *}$ Department of Economics, Umeå University, SE-901 87 Umeå, Sverige (Sweden).
}

(Multinational Finance Journal, 2009, vol. 13, no. 1/2, pp. 135-154)

(C) Multinational Finance Society, a nonprofit corporation. All rights reserved. DOI: $10.17578 / 13-1 / 2-6$ 
capital gains. ${ }^{1}$ Several studies since have used regime-shifts in tax policy to infer the effects of taxation (e.g. Poterba and Summers, 1984; Robin, 1991; Skinner, 1993), the results of which appear to vary considerably.

The effects of taxation on corporate dividend policies have also been addressed frequently. A traditional view (e.g., Feldstein, 1970) is that changes in dividend taxation reduce the net return on investment and thus affect dividend pay-out by firms. The "irrelevance argument", on the other hand, suggests that changes in dividend taxation do not affect dividends or investment since the marginal investor is assumed to be taxed indifferently between dividends and capital gains. ${ }^{2}$ There have been a number of recent empirical analyses of the U.S. dividend tax-cut in 2003 (Blouin, Raedy and Shackelford, 2004; Brown, Liang and Weisbenner, 2004; Poterba, 2004; Chetty and Saez, 2005).

In this paper, we use Swedish data to infer the effects of taxation on dividend payments and ex-day price changes. A crucial issue in many empirical studies is identification of the "marginal shareholder". Since taxes on dividends and capital gains in most countries are considered part of personal-income taxation, and since tax schedules are usually progressive, private investors usually face different marginal tax-rates. But under the 1991 Swedish tax-reform, dividends and capital gains became taxed separately from ordinary income, at a flat rate. During 1991 to 1995 there were then three successive tax regimes for domestic individual investors: initially dividends and capital gains were taxed at the same rate $(30 \%)$; then one where dividends were taxed more heavily; and finally one where capital gains were taxed more heavily.

The paper contributes to the literature on dividend payments and ex-day price changes in two ways. First, the fact that dividends and capital gains were separated from other personal income and taxed at flat rates, makes it possible to include direct tax measures in the empirical analysis. Second, all domestic individual investors faced the same flat tax rate during the study period, implying that a positive relation between the DOR and dividend yields cannot be a consequence of tax-induced clienteles among domestic individual investors. ${ }^{3}$

1. This hypothesis is hereafter referred to as the tax-clientele hypothesis.

2. Poterba and Summers (1985) discuss various hypotheses related to dividend taxation, dividend policy, and investment.policy, and investment.

3. As noted by Lakonishok and Vermaelen (1986), this often documented positive 
The results here show that the decision to pay dividends can be affected by having different tax rates on dividends and capital gains facing domestic individual investors. The effects are substantial, and robust to changes in specification. The direct impact on stock prices around the ex-dividend day is less clear. We also find the $D O R$ positively related to dividend yields (statistically significant at 10\%). As noted above, in the Swedish tax-system this relation cannot be explained by tax-induced clienteles among domestic individual investors, indicating that this result might be caused by tax-indifferent institutional investors who prefer to trade with high dividend yield stocks.

The next section describes previous studies on determinants of dividend pay-outs and ex-dividend price-behavior. Section III then describes the data used here and the tax-policy changes in Sweden during 1991-95. Section IV describes the empirical models, while section $\mathrm{V}$ presents the results. The final section summarizes and draws conclusion

\section{Previous Studies}

\section{A. Explaining the Dividend Pay-Out}

Dividends may be used as a signalling device (Battacharya, 1979; Miller and Rock, 1985; Ambarish, John and Williams, 1987), providing investors with information about future growth opportunities of firms that is not available elsewhere. Or dividends might be used as an instrument to reduce agency-costs (Jensen and Meckling, 1976; Easterbrook, 1984), restricting managerial discretion. But a number of studies (e.g., Bradley et al., 1998; Charitou and Vafeas, 1998) have been able to predict dividends with precision using firms' free cashflows, implying that they reflect high liquidity. Firms may also be more willing to pay high dividends when market-risk is relatively low. The classical model (Lintner, 1956) suggests, however, that dividends are mainly determined by the amount of previous dividends.

As noted earlier, differences in taxation might also influence the amount of dividends. In most countries, dividends are taxed at a higher

relation can be a consequence of either tax-induced clienteles or arbitrage-trading by professional institutional investors, or both. In a progressive tax setting it is impossible to distinguish empirically between these two competing hypotheses using market price data. 
rate than capital gains, creating a preference for low-dividend policies. But where they are treated as ordinary income subject to progressive rates both dividends and capital gains may be taxed differently for different domestic individual investors, those with high marginal tax-rates preferring low-dividend stocks and those with lower marginal rates preferring high-dividend stocks, thus creating tax-induced dividend-clienteles.

Bell and Jenkinson (2002) offer a related explanation focusing on ownership, with evidence that the marginal traders on the UK stock market during 1995-1999 were pension funds. Institutional investors usually face the same tax-rate on dividends and capital gains, while dividends are often tax penalized for private investors (Boyd and Jagganathan, 1994). This can provide incentive for institutional investors to demand high dividends, in order to develop arbitrage-trading strategies around the ex-dividend day Kalay (1982, 1984). They may also demand high dividends to force firms to go to the capital market for future funds, thus reducing agency costs (Zechhauser and Pund, 1990; Short et al., 2002).

\section{B. Studying Ex-Dividend Price-Behavior: The Traditional Approach}

The ex-dividend price-change has traditionally been analyzed using the DOR as the dependent variable. Elton and Gruber (1970) showed in a classic paper that it was determined by the net-of-marginal-tax ratio between dividends and capital gains, i.e., DOR $=\left(1-\tau_{d}\right) /\left(1-\tau_{g}\right)$, where $\tau_{d}$ is the tax-rate on dividends and $\tau_{g}$ is the tax-rate on capital gains. This implies that, where capital gains are taxed more favorably than dividends, the DOR should be lower for stocks which attract shareholders in high income-tax brackets. To illustrate this result, assume that dividends are fully taxed as ordinary income and that $60 \%$ of capital gains realisations are excluded from taxation. For an investor with a marginal tax rate of $60 \%$, the DOR is then given by $(1-0.6) /(1$ $-0.24)=0.53$; while the $D O R$ for a stockholder in a lower income tax bracket (e.g., $\left.\tau_{d}=40 \%\right)$ is given by $(1-0.4) /(1-0.16)=0.71$.

This model suggests that the DOR should change when the relative taxation of dividends and capital gains for domestic individual investors changes. A number of studies (Booth and Johnston, 1984; Poterba and Summers, 1984; Barclay, 1987; Michaely, 1991; Robin, 1991; Athanassakos and Fowler, 1993; Skinner, 1993; de Ridder and Södersten, 1995; and Wu and Hsu, 1996) have used such regime-shifts 
to investigate the behavior of shareholders in the period around the ex-dividend day. These studies often regress

$$
\frac{P_{i, t}^{c}-P_{i, t}^{x}}{D_{i, t}}=\beta_{0}+\beta_{1}\left(\frac{D_{i, t}}{P_{i, t}^{c}}\right)+\sum_{j=1}^{n} \delta_{j} I_{j}+\varepsilon_{i, t}
$$

where the dependent variable is the DOR for stock $i$ in year $t, P_{i, t}^{c}$ and $P_{i, t}^{x}$ are the closing prices on the cum- and the ex-dividend days, respectively, $D_{i, t}$ is the dividend per share, $\beta_{0}$ is a constant, and $\varepsilon_{i, t}$ is the error-term. Changes in the relative taxation of dividends and capital gains are indicated by $I_{j}$, a dummy that is equal to one during a specific tax regime $j .{ }^{4}$

Some of the earlier studies (e.g., Poterba and Summers, 1984; Barclay, 1987; Robin, 1991) found that taxes influenced ex-dividend price-behavior, while others (e.g., Skinner, 1993; de Ridder and Södersten, 1995) found that they did not. Most found the DOR positively related to dividend-yield, perhaps as a result of tax-induced clienteles as discussed earlier (Elton and Gruber, 1970).

Kalay (1982, 1984) and Miller and Scholes (1982) argued that marginal tax-rates cannot be derived from the DOR because institutional and individual investors often face different tax-rules, e.g., institutional investors may be taxed equally on dividends and capital gains, while dividends are tax-penalized for individuals (Boyd and Jagannathan, 1994). Kalay $(1982,1984)$ showed that institutional investors may be able to exploit such tax-differences to make arbitrage profits and that such profit opportunities will be directly proportional to the dividend-yield.

Hence, a positive relation between the DOR and dividend-yield might occur either because of tax-induced clienteles or because of arbitrage trading by institutional investors. Previous ex-dividend price-studies have not been able to empirically discriminate between these two hypotheses.

\section{Studying Ex-Dividend Price Behavior: The Modern Approach}

This traditional approach focusing on the DOR has been critized

4. The use of the DOR as the dependent variable means that the sample must be restricted to firms paying dividends; however, in every period some firms choose not to pay dividends, which restricts the sample. 
because the error-term may be heteroskedastic (Lakonishok and Vermaelen, 1986; Barclay, 1987; and Michaely, 1991). Boyd and Jagganathan (1994) instead used the percentage price-change between the cum- and ex-dividend days as the dependent variable, as did Green and Rydqvist (1999), McDonald (2001), Bell and Jenkinson (2002), and Florensen and Rydqvist (2002). In this approach one regresses

$$
\frac{P_{i, t}^{c}-P_{i, t}^{x}}{P_{i, t}^{c}}=\gamma_{0}+\gamma_{1}\left(\frac{D_{i, t}}{P_{i, t}^{c}}\right)+\sum_{j=1}^{n} \eta_{j}\left(\frac{D_{i, t}}{P_{i, t}^{c}} \times I_{j}\right)+\varepsilon_{i, t}
$$

where the dependent variable is the percentage price-change between the cum- and ex-dividend days for stock $i$ in year $t, D_{i, t}$ is again the dividend; $\gamma_{0}$ is a constant; $\varepsilon_{i, t}$ is the error-term; and $I_{j}$ is a dummy equal to one during a specific tax-regime $j$, zero otherwise. ${ }^{5}$

In addition to tax-induced clienteles and arbitrage-trading, non-tax factors may influence ex-dividend day price changes. For example, Frank and Jagganathan (1998) showed that prices in the Hong Kong stock market dropped less than the dividend amount, due to microstructure-effects and transaction-costs. Bali and Hite (1998) also provided some empirical evidence that the tick-effect, i.e., that stock prices change discretely, also leads to a DOR less than one. The constant $\left(\gamma_{0}\right)$ was included in the model to control for such effects.

The new approach produces two parameters: an intercept-coefficient (the constant, $\gamma_{0}$ ) and a slope-coefficient. Boyd and Jagganathan (1994) showed that the intercept-coefficient will be negative (and statistically significant) if non-tax factors are important for ex-dividend price-behavior, while the slope-coefficient estimates the DOR. Hence, this approach makes it possible to carry out more detailed hypothesis-testing.

\section{Data and Swedish Tax Regimes}

Daily closing-prices from the Stockholm Stock Exchange (SSE) during 1991-1995 are used here to study price-changes between cum- and

5. In contrast to the traditional approach, the sample does not need to be restricted to firms paying dividends although previous studies have done so anyway. 
ex-dividend days in Sweden. ${ }^{6}$ The number of firms varies from 35 in 1991 to 94 in 1995, resulting in 302 ex-dividend dates. Firm-specific information, such as the market-to-book ratio, number of employees, and dividend amount is from Bonniers Findata. Information on ex-dividend dates is from the Swedish patent and registration office (PRV), while dividend announcement-dates are from SIX Trust. Finally, shares of foreign ownership are from the yearly volume Ägarna och Makten provided by SIS Ägarservice.

Ex-dividend price changes on the SSE during this period are particularly interesting to study because, as noted earlier, a major tax-reform was implemented in Sweden in 1991. The Swedish tax reform in 1991 has been classified (see Agell et al., 1998, p. 1) as the "most far-reaching tax reform in any western industrialized country" in recent decades.

Dividends and capital gains were before the 1991 tax reform, as in most other countries, taxed as ordinary income at progressive rates and the marginal tax-rate on capital gains had been lower than that on dividends. In addition, long-term capital gains were taxed more favorably compared to short-term capital gains since investors were allowed to exclude $60 \%$ of capital gains realized after two years.

All this changed with the 1991 tax reform. In fact, the Swedish tax reform in 1991 was more comprehensive than the often studied US Tax Reform Act of 1986. In the latter reform, tax cuts were estimated to reduce revenues with 1-2\% of GDP; whereas pre-estimates of the 1991 tax reform in Sweden suggested a revenue loss of approximately $6 \%$ of GDP due to rate cuts (see Agell et al., 1998). The 1991 tax reform meant that marginal tax rates were dramatically lowered, various tax shelters were eliminated, the value added tax (VAT) was broadened, and the corporate tax rate was reduced from $57 \%$ to $30 \%$.

A notable feature of the Swedish tax reform was that ordinary income and capital income became taxed separately, with dividends and capital gains taxed at a flat rate of 30\%. However, already in 1992 a newly elected non-socialistic government reduced the capital gains

6. The period before 1991 is excluded since capital gains and dividends before the Swedish tax reform in 1991 were taxed as ordinary income at progressive rates, making it impossible to include direct tax measures in the empiricial analysis. The period after 1995 is excluded because the data used in this study only was available until 1995 . However, the period 1991-1995 is especially interesting to study because we can observe a number of tax rate changes on dividends and capital gains in the Swedish flat tax rate system during that period. After 1995, no such changes occured. 
tax-rate to $25 \%$. It was further reduced to $12.5 \%$ in 1994 , while the tax on dividends was removed entirely. Uniform $30 \%$ taxes were reinstated when the Social democratic party regained legislative power in 1995 and the tax rates on dividends and capital gains have remained unchanged since then. ${ }^{7}$

Hence, there were four different periods and three different relationships between the tax-rates on capital gains and dividends during the study period (table 1 , below). ${ }^{8}$ Compared to previous ex-dividend studies, these changes provide greater variation to study.

Definitions of all the variables included in the empirical analysis, as well as means and standard deviations, are given in table 2 . The variables included are further discussed in section IV.

A majority of the firms (225 of 302) paid dividends, the average yield being $2.1 \%$. The average yield is thus larger than those in previous ex-dividend studies (e.g., Lakonishok and Vermaelen, 1986), which is not surprising, since dividends are paid yearly in Sweden, rather than quarterly as in the US.

\section{Empirical Models}

We estimate equations for both the ex-dividend price-change and the dividend amount, and we will start with the latter.

\section{A. Estimating the Determinants of Dividend Payments}

Previous studies usually restricted attention to firms paying dividends. However, since dividends are censored at zero, valuable information may be lost by excluding non-paying firms (Kim and Maddala, 1992).

7. The tax rate changes were implemented in January and were announced a couple of months before the implementation dates. This should have no influence on ex-day price changes since they reflect actual tax rates at the ex-dividend dates. Dividend payments are typically announced in the beginning of the year and paid around 3 months later. This means that the same tax rates applies for the announcement and the implementation date. On the other hand, there is a possibility that the omission of the dividend tax in 1994, and the re-introduction of a 30 percent dividend tax rate in 1995, was anticipated. Hence, a negative relation between dividend payments and dividend taxes might reflect timing behavior, i.e., a transitory and not a permanent tax effect.

8. Note that capital gains are taxed on realization rather than accrual, implying that the effective tax rate is lower than the headline tax rate displayed in table 1. 
TABLE 1. Tax Regimes for Individual Domestic Investors in Sweden, 1991-95

\begin{tabular}{lccc}
\hline Year & $\begin{array}{c}\text { Dividends } \\
\text { tax-rate }\end{array}$ & $\begin{array}{c}\text { Capital gains } \\
\text { tax-rate }\end{array}$ & $\begin{array}{c}\text { Tax } \\
\text { ratio }^{a}\end{array}$ \\
\hline 1991 & $30 \%$ & $30 \%$ & 1 \\
$1992-93$ & $30 \%$ & $25 \%$ & 0.933 \\
1994 & $0 \%$ & $12.5 \%$ & 1.143 \\
1995 & $30 \%$ & $30 \%$ & 1 \\
\hline
\end{tabular}

Note: ${ }^{a}$ Given by $\left(1-\tau_{d}\right) /\left(1-\tau_{g}\right)$; where $\tau_{d}=$ marginal tax-rate on dividends and $\tau_{g}=$ marginal tax-rate on capital gains.

In addition to the standard least-squares regression model, we therefore use a censored-normal regression model (Tobit model) to estimate the determinants of dividends.

Our main attention is focused on the effects of dividend and capital-gains taxation, but it is difficult to estimate the effects of each of two taxes separately, since the marginal tax-rate on dividends remained the same, except for 1994. Unfortunately, the period under study also coincides with a major downturn of the Swedish economy, making it difficult to separate changes in tax-rates from changes in the business cycle. Therefore, in order to address the effects of taxation and at the same time control for the business cycle, taxation is measured as the net-of-tax ratio (TAX RATIO) between the dividend tax and the capital gains tax, defined as $\left(1-\tau_{d}\right) /\left(1-\tau_{g}\right)$. The hypothesis to be explored is that, other things equal, it should have a positive effect on dividends. To capture the business cycle, the regressions are conditioned on GDP per capita at fixed prices (table 2 below provides definitions of all variables).

In the Tobit model, $D_{i, t}^{*}$ is a latent variable describing the dividend per share for stock $i$ in year $t$, with equation

$$
\begin{gathered}
D_{i, t}^{*}=\alpha_{0}+\alpha_{1}\left(D_{i, t-1}\right)+\alpha_{2}\left(T A X \operatorname{RATIO}_{t}\right)+\alpha_{3}\left(G D P_{t}\right) \\
+\alpha_{4}\left(O-\operatorname{LIST}_{i, t}\right)+\theta F_{i, t}+v_{i, t}
\end{gathered}
$$

where TAX RATIO and GDP are defined as above; $D_{i, t-1}$ is the dividend per share in the previous period; $O$ - LIST is a dummy, equal to one if the firm's shares are available on any list besides the so-called A-list on 
TABLE 2. Definitions, Means and Sources of Variables.

\begin{tabular}{|c|c|c|}
\hline Variable & $\begin{array}{l}\text { Mean } \\
(\mathrm{SD})\end{array}$ & Definition and source \\
\hline DIVIDEND & $\begin{array}{l}2.20 \\
(2.904)\end{array}$ & $\begin{array}{l}\text { Dividend per share (SEK) measured in } 1995 \\
\text { consumer prices. Source: Bonniers Findata }\end{array}$ \\
\hline MARKET-TO-BOOK & $\begin{array}{l}1.924 \\
(7.68)\end{array}$ & $\begin{array}{l}\text { Ratio of market value to book value. Source: } \\
\text { Bonniers Findata }\end{array}$ \\
\hline LOG EMPLOYMENT & $\begin{array}{l}7.10 \\
(2.949)\end{array}$ & $\begin{array}{l}\text { The logarithm of the number of employed } \\
\text { individuals. Source: Bonniers Findata }\end{array}$ \\
\hline CASH-FLOW & $\begin{array}{l}22.08 \\
(21.02)\end{array}$ & $\begin{array}{l}\text { Cash-flow per share (SEK) measured in } 1995 \\
\text { consumer prices. Source: Bonniers Findata }\end{array}$ \\
\hline EARNINGS & $\begin{array}{c}6.17 \\
(14.92)\end{array}$ & $\begin{array}{l}\text { Net earnings per share (SEK) measured in } 1995 \\
\text { consumer prices. Source: Bonniers Findata }\end{array}$ \\
\hline FOREIGN SHARE & $\begin{array}{c}0.155 \\
(0.178)\end{array}$ & $\begin{array}{l}\text { The share of stocks held by foreigners at the end } \\
\text { of December each year. Source: SIS Ägarservice. }\end{array}$ \\
\hline BETA & $\begin{array}{l}0.605 \\
(2.20)\end{array}$ & $\begin{array}{l}\text { The beta value, estimation given by endnote } 10 \text { in } \\
\text { the paper. Source: Stockholm Stock Exchange }\end{array}$ \\
\hline DIVIDEND TAX & $\begin{array}{c}0.220 \\
(0.133)\end{array}$ & $\begin{array}{l}\text { The tax on dividends paid by domestic individual } \\
\text { investors in Sweden. Source: National Tax Board }\end{array}$ \\
\hline CAPITAL GAINS TAX & $\begin{array}{c}0.238 \\
(0.072)\end{array}$ & $\begin{array}{l}\text { The tax on capital gains paid by domestic } \\
\text { individual investors in Sweden. Source: National } \\
\text { Tax Board }\end{array}$ \\
\hline TAX RATIO & $\begin{array}{c}1.018 \\
(0.081)\end{array}$ & $\begin{array}{l}\text { The net-of-tax ratio, calculated from the dividend } \\
\text { tax and the capital gains tax. Source: National Tax } \\
\text { Board. }\end{array}$ \\
\hline$O-L I S T$ & $\begin{array}{c}0.313 \\
(0.464)\end{array}$ & $\begin{array}{l}\text { Dummy, equal to one if the stock is listed on the } \\
\text { O-list or the OTC-list. Source: Stockholm Stock } \\
\text { Exchange. }\end{array}$ \\
\hline DOR & $\begin{array}{l}0.535 \\
(2.12)\end{array}$ & $\begin{array}{l}\text { Price-drop-to-dividend ratio. Source: Stockholm } \\
\text { Stock Exchange and Bonniers Findata. }\end{array}$ \\
\hline EX-PRICE CHANGE & $\begin{array}{c}0.013 \\
(0.049)\end{array}$ & $\begin{array}{l}\text { The percent price-change between the cum- and } \\
\text { ex-dividend Days. Source: Stockholm Stock } \\
\text { Exchange }\end{array}$ \\
\hline DIVIDEND YIELD & $\begin{array}{c}0.021 \\
(0.019)\end{array}$ & $\begin{array}{l}\text { Dividend per share divided by the price on the } \\
\text { cum-dividend day. Source: Stockholm Stock } \\
\text { Exchange and Bonniers Findata. }\end{array}$ \\
\hline$G D P$ & $\begin{array}{l}203.3 \\
(3.66)\end{array}$ & $\begin{array}{l}\text { GDP in } 1000 \text { 's of SEK per capita at } 1995 \text { consumer } \\
\text { prices. Source: Statistics Sweden. }\end{array}$ \\
\hline $\begin{array}{l}\text { Number of } \\
\text { observations. }\end{array}$ & $302 / 225$ & $\begin{array}{l}\text { Full sample/ those stocks that paid dividends during } \\
\text { 1991-95. }\end{array}$ \\
\hline
\end{tabular}

the SSE; $F_{i, t}$ is a vector of firm-specific characteristics; and $v_{i, t}$ is an error-term, assumed normally distributed with constant variance. The vector $\theta$ and $\alpha_{0}-\alpha_{4}$ are parameters to be estimated

Lintner (1956) argued that dividends are mainly determined by the 
dividend in the previous period, so we expect $\alpha_{1}$ to be positive. The $O$ - LIST variable is assumed to capture maturity of the firm; those not on the A-list are expected to pay lower dividends.

The firm-specific vector, $F_{i, t}$, contains variables commonly used in the analysis of dividend pay-outs. MARKET - TO - BOOK is the ratio of market value to book value, assumed to capture growth-opportunities of the individual firm. ${ }^{9}$ According to the dividend-signaling hypothesis (discussed in section II), such growth firms pay high dividends to inform investors about their growth prospects, so MARKET - TO $B O O K$ should be positively related to dividends. On the other hand, Gaver and Gaver (1993) suggest that growth firms might pay low dividends to exploit their high growth opportunities, so there is no clearcut hypothesis about the sign of this coefficient.

EARNINGS is net per share; more profitable firms are assumed to pay higher dividends than less profitable ones. CASHFLOW (from operation per share) is included to reflect liquidity; we expect firms with higher liquidity to pay higher dividends. LOG EMPLOYMENT is the (log of the) number of employees expressing the size of the firm; as agency-costs associated with managerial discretion are thought to increase with size, high dividends might be paid to reduce them. Therefore, we expect that dividends should be increasing in employment. BETA is a measure of the riskiness of the stock, expected to decrease the dividend. ${ }^{10}$

Short et al. (2002) found that institutional ownership may influence a firm's dividend policy, but we have no information on institutional ownership. However, the variable FOREIGN SHARE, indicating the share of stocks held by foreigners, is included since the typical foreign owner in Sweden is an institutional investor (Dahlquist and Robertsson, 2001).

The censoring-rule for the Tobit regression can be written as

9. The Market-to-Book Ratio is the ratio of the share price to the book value per share. It is calculated as the market value of a company's common shares divided by stockholders' equity, where the latter is defined as assets minus liabilities as carried on a company's balance sheet. The ratio thus compares the market's valuation of a company to the value of that company as indicated on its financial statements.

10. The beta value for stock $i$ in year $t\left(b_{i t}\right)$ is estimated, using daily data from the year preceding the dividend pay-out, with $R_{i, s}=a_{i}+b_{i, t} R_{m, s}+e_{i, s}$, where $R_{i, s}$ is the individual return on stock $i$ on day $s ; a_{i}$ is a constant; $R_{m, s}$ is the market return on day $s$ (approximated by Affärsvärlden's value weighted general index); and $e_{i, s}$ is the error-term. 


$$
\begin{aligned}
D_{i, t} & =D_{i, t}^{*} \quad \text { if } \quad D_{i, t}^{*}>0 \\
& =0 \quad \text { otherwise }
\end{aligned}
$$

In the least squares model, only positive values of the dependent variable are included, implying that $D_{i, t}=D_{i, t}^{*}$.

\section{B. Estimating Ex-Dividend Price Behavior}

Next we estimate price-changes on the ex-dividend day, using both the traditional approach where the dependent variable is the price-drop-to-dividend ratio $(D O R)$ and the new approach, comparing ex-dividend to the cum-dividend prices.

As noted earlier, in the traditional approach the sample must be limited to firms paying dividends. The estimating equation is

$$
\frac{P_{c, i, t}-P_{x, i, t}}{D_{i, t}}=\beta_{0}+\beta_{1}\left(\frac{D_{i, t}}{P_{c, i, t}}\right)+\eta\left(T A X \text { RATIO }_{t}\right)+\varepsilon_{i, t}
$$

which is almost identical to equation (ex-ratio), except that there are no dummies for tax regimes, because the flat tax-rates for domestic individual investors on dividends and capital gains, following the Swedish tax-reform in 1991, allow inclusion of direct measure of their differential tax-treatment $\left(T A X R A T I O_{t}\right)$. Tax-rate changes can thus be separated from other period-specific developments, such as technological changes or the business cycle. During the years when dividends and capital gains were taxed equally at a flat rate of $30 \%$ irrespective of total taxable income (i.e., 1991 and 1995), TAX $R A T I O_{91,95}=1$. For the period 1992-93,

$$
T A X \operatorname{RATIO}_{92,93}=\frac{(1-0.3)}{(1-0.25)}=0.933
$$

and for 1994,

$$
\operatorname{TAXRATO}_{4}=\frac{(1-0)}{(1-0.125)}=1.14
$$


Thus the effect of changes in the relative taxation of dividends and capital gains is measured by $\eta$.

The 1991 Swedish tax reform provides a unique opportunity to examine the tax-clientele hypothesis using aggregate price-data from the stock market. As discussed earlier, the documented positive relation between the DOR and dividend yield could be a consequence of either tax-induced clienteles or arbitrage-trading by professional institutional investors, or both (Lakonishok and Vermaelen, 1986). Previous studies of ex-dividend price-behavior have not been able to distinguish empirically between these two competing hypotheses. However, the tax-clientele hypothesis implicitly assumes that dividends and capital gains are taxed as ordinary income. When they are separated and taxed as investment-income subject to a flat rate, as in Sweden after 1991, a positive relation between the DOR and dividend yield cannot be explained by tax induced clienteles. Hence, if ex-dividend price-changes, as suggested by Elton and Gruber (1970), are solely driven by the differential tax-treatment of dividends and capital gains, then it should happen that $\eta=1$ and $\beta_{0}, \beta_{1}=0$.

The estimating equation for the new approach is

$$
\begin{aligned}
\frac{P_{c, i, t}-P_{x, i, t}}{P_{c, i, t}}=\gamma_{0} & +\gamma_{1}\left(\frac{D_{i, t}}{P_{c, i, t}} \times I_{91,95}\right)+\gamma_{2}\left(\frac{D_{i, t}}{P_{c, i, t}} \times I_{92-93}\right) \\
& +\gamma_{3}\left(\frac{D_{i, t}}{P_{c, i, t}} \times I_{94}\right)+\varepsilon_{i, t}
\end{aligned}
$$

where the dependent variable (EX - PRICE CHANGE) is the percent price-change between the cum- and ex-dividend days for stock $i$ in year $t$; and $I_{91,95}, I_{92-93}$ and $I_{94}$ are dummies for the tax-regimes during the study period (table 1, above).

With the new approach we thus estimate the DORs directly, i.e., the parameters $\gamma_{1}, \gamma_{2}$, and $\gamma_{3}$ measure ex-dividend price-changes relative to the dividend. Given the flat tax-rates, there are two null hypotheses, depending upon who is the marginal shareholder: If domestic individual investors are driving the market, we would expect $\gamma_{1}=1, \gamma_{2}=0.933$, and $\gamma_{3}=1.143$ (again see table 1 above); and the null hypothesis $H_{0}:\left(\gamma_{1}, \gamma_{2}\right.$, $\left.\gamma_{3}\right)=(1,0.933,1.143)$ can be tested against an unrestricted alternative. But for institutional investors (facing identical tax-rates) driving the 
TABLE 3. Determinants of Dividend Pay-outs (Robust-White t-values in parentheses).

\begin{tabular}{|c|c|c|c|c|}
\hline Independent variable & $\begin{array}{c}\text { OLS } \\
\text { I }\end{array}$ & II & $\begin{array}{c}\text { TOBIT } \\
\text { III }\end{array}$ & IV \\
\hline CONSTANT & $\begin{array}{l}-30.17 * * * \\
(-5.10)\end{array}$ & $\begin{array}{l}-32.20 * * * \\
(-5.50)\end{array}$ & $\begin{array}{l}-33.41 * * * \\
(-5.18)\end{array}$ & $\begin{array}{l}-33.49 * * * \\
(-5.58)\end{array}$ \\
\hline DIVIDEND ${ }_{\mathrm{t}-1}$ & $\begin{array}{l}0.987 * * * \\
(11.63)\end{array}$ & $\begin{array}{l}0.918^{* * *} \\
(10.81)\end{array}$ & $\begin{array}{l}1.031^{* * * *} \\
(12.75)\end{array}$ & $\begin{array}{l}0.951^{* * *} \\
(11.03)\end{array}$ \\
\hline TAX RATIO & $\begin{array}{l}2.975 * * * \\
(3.61)\end{array}$ & $\begin{array}{l}2.626^{* * * *} \\
(2.64)\end{array}$ & $\begin{array}{l}2.373 * * \\
(2.58)\end{array}$ & $\begin{array}{l}1.990 * * \\
(1.97)\end{array}$ \\
\hline$G D P$ & $\begin{array}{l}0.136 * * * \\
(4.87)\end{array}$ & $\begin{array}{l}0.146^{* * *} \\
(5.35)\end{array}$ & $\begin{array}{l}0.154 * * * \\
(4.99)\end{array}$ & $\begin{array}{l}0.151^{* * *} \\
(5.40)\end{array}$ \\
\hline OLIST & $\begin{array}{c}0.023 \\
(0.08)\end{array}$ & $\begin{array}{l}-0.043 \\
(-0.16)\end{array}$ & $\begin{array}{l}-0.297 \\
(-0.99)\end{array}$ & $\begin{array}{l}-0.034 \\
(-0.12)\end{array}$ \\
\hline MARKET-TO-BOOK & & $\begin{array}{l}-0.057 * * \\
(-2.04)\end{array}$ & & $\begin{array}{l}-0.061 * * \\
(-2.27)\end{array}$ \\
\hline EARNINGS & & $\begin{array}{r}0.011 \\
(0.92)\end{array}$ & & $\begin{array}{l}0.019 * \\
(1.66)\end{array}$ \\
\hline CASH-FLOW & & $\begin{array}{c}0.016 \\
(1.32)\end{array}$ & & $\begin{array}{c}0.014 \\
(1.18)\end{array}$ \\
\hline LOG EMPLOYMENT & & $\begin{array}{c}0.008 \\
(0.16)\end{array}$ & & $\begin{array}{l}0.113^{* *} \\
(2.16)\end{array}$ \\
\hline BETA & & $\begin{array}{r}0.016 \\
(0.90)\end{array}$ & & $\begin{array}{l}-0.013 \\
(-0.68)\end{array}$ \\
\hline FOREIGN SHARE & & $\begin{array}{l}-0.342 \\
(-0.75)\end{array}$ & & $\begin{array}{l}-0.537 \\
(-1.17)\end{array}$ \\
\hline Number of observations & 225 & 217 & 302 & 291 \\
\hline $\begin{array}{l}\text { Log likelihood } \\
\text { ADJ. } R^{2}\end{array}$ & $\begin{array}{r}-383.50 \\
0.79\end{array}$ & $\begin{array}{r}-352.14 \\
0.82\end{array}$ & -352.88 & -316.69 \\
\hline
\end{tabular}

Note: The dependent variable is the dividend per-share calculated in 1995 prices. Variable definitions are given in table $2 . *$ denotes significance at the ten-percent level. $* *$ denotes significance at the five-percent level. *** denotes significance at the one-percent level.

market, the null hypothesis $H_{0}:\left(\gamma_{1}, \gamma_{2}, \gamma_{3}\right)=(1,1,1)$ can be tested the same way.

\section{Results}

Table 3 presents estimation results from four models of the determinants of dividend pay-outs. Models I and II are OLS models, while Models III and IV are Tobit. For comparison, Models I and III are stripped-down 
versions with firm-specific information left out.

As indicated by the parameters on DIVIDEND ${ }_{t-1}$, dividends were highly persistent, in accordance with previous studies (e.g., Fama and Babiak, 1968) which found that firms' dividend policies were seldom subject to major revision. The parameter associated with GDP is positive and statistically significant in all specifications, indicating that dividends varied pro-cyclically over the business cycle. It does not appear important to control for list effects, however; the parameter on the dummy variable $O$ - LIST is not significant and varies in sign.

Among the firm variables, the MARKET - TO - BOOK ratio is negative and significant in both OLS and Tobit specifications. Since it is assumed to reflect growth possibilities, the sign suggests that high-growth firms pay lower dividends, either to exploit those possibilities or because some of them are less-mature firms that have not yet started to pay dividends. There do in fact appear to be size-effects, as measured by LOG EMPLOYMENT, when non-dividend firms are included in the analysis (the Tobit model); size may affect the decision to pay dividend more than the amount. The other firm-specific variables are not significant though both EARNINGS and CASHFLOW have the expected signs.

The net-of-tax ratio (TAX RATIO) is significant and positive in all specifications, with the parameter somewhat smaller when firm-specific variables are included. Using the OLS result of Model II, the variation in dividends because of taxation can be calculated to over 7\%. ${ }^{11}$ And more radical comparisons can be made: Using the parameter estimate in column 4 , table 3 , suppose that dividends and capital gains have been taxed at $30 \%$, and policymakers abolish the dividend tax; average dividends would increase $40 \%$. If the capital-gains tax were instead abolished, dividends would drop about $28 \%$. Thus, large tax-reforms may have substantial effects on dividends.

Estimation results regarding ex-dividend price behavior are presented in table 4 below. Results from the traditional approach, where the DOR is the dependent variable, is given in the first column; whereas results from the new approach, where EX - PRICE CHANGE is the dependent variable, are presented in the second column.

The parameter on DIVIDEND YIELD is significant (at 10\%) and

11. The parameter associated with taxation is multiplied times the ratio of the standard deviation of TAX RATIO to the standard deviation of DIVIDEND for the dividend-paying firms, i.e., $2.626 *(0.081 / 2.86)=0.074$. 
TABLE 4. Price Changes on the Ex-dividend Day. (Robust-White t-values in parentheses).

\begin{tabular}{|c|c|c|}
\hline Independent variable & $D O R$ & EX - PRICE CHANGE \\
\hline CONSTANT & $\begin{array}{l}-1.981 \\
(-0.73)\end{array}$ & $\begin{array}{l}-0.010 * * \\
(-2.07)\end{array}$ \\
\hline DIVIDEND YIELD & $\begin{array}{l}19.73^{*} \\
(1.74)\end{array}$ & \\
\hline TAX RATIO & $\begin{array}{r}1.910 \\
(0.80)\end{array}$ & \\
\hline DIVIDEND YIELD $_{91,95}$ & & $\begin{array}{l}1.041 * * * \\
(5.95)\end{array}$ \\
\hline DIVIDEND YIELD $_{92,93}$ & & $\begin{array}{l}0.949 * * * \\
(4.88)\end{array}$ \\
\hline DIVIDEND YIELD $_{94}$ & & $\begin{array}{l}1.335 * * * \\
(6.10)\end{array}$ \\
\hline Number of observations & 225 & 302 \\
\hline ADJ.R $R^{2}$ & 0.014 & 0.153 \\
\hline
\end{tabular}

Note: $*$ denotes significance at the ten-percent level. $* *$ denotes significance at the five-percent level. $* * *$ denotes significance at the one-percent level.

positive, indicating higher $D O R$ for higher dividend-yield stocks. Sincedividends and capital gains were taxed at flat rates independent of ordinary income, this cannot be explained by tax-induced clienteles. The parameter on the net-of-tax ratio (TAXRATIO) is not significant, though positive.

In the new approach (the second column), the DORs are estimated directly, tracking differential taxation over time fairly closely. For 1991 and 1995, the estimated DOR is 1.04 (corresponding TAX RATIO is 1, from table 1). For 1992-93 the DOR is 0.95 (TAX RATIO 0.93), and for 1994 it is 1.33 (TAX RATIO 1.14). The hypothesis that private individuals were the marginal investors, $H_{0}:\left(\gamma_{1}, \gamma_{2}, \gamma_{3}\right)=(1,0.933$, 1.143), cannot be rejected using an F-test $(F(3,298)=0.34$; -value $=$ $0.80)$, nor can the hypothesis $H_{0}:\left(\gamma_{1}, \gamma_{2}, \gamma_{3}\right)=(1,1,1)$ that equally-taxed institutional investors were driving market prices $(F(3,298)=1.37$; $\mathrm{p}$-value $=0.25)$. However, the much higher $\mathrm{p}$-value for individual investors favors that hypothesis. ${ }^{12}$

12. A possible source of bias is if the ex-price change and dividends are affected by the same unobserved factors. This would be the case if dividends are affected by unobserved information and this information is revealed after the cum-dividend day. We have therefore estimated models where dividends are potentially endogenous in the EX - PRICE CHANGE equation. However, the hypothesis of (weak) exogeneity could not be rejected. 


\section{Summary and Conclusions}

To our knowledge, this is the first attempt to study the determinants of dividends and ex-dividend day price-changes jointly, which is important because the effects of the taxation of dividends and capital gains on ex-dividend prices cannot be treated independently from its effects on dividends themselves.

Swedish stock-market data from 1991-1995 was used to analyze the effects of taxation on dividend payments and ex-dividend price changes. This data is especially suitable since dividends and capital gains were taxed at flat rates separately from ordinary income. It was thus possible to test hypotheses regarding the role of private investors in much more detail than is usually the case. In contrast to previous studies, we also incorporated zero-dividend stocks when analyzing the percentage change between cum and ex-dividend prices.

The results indicate that dividends were influenced by the taxation of dividends and capital gains. This effect found is relatively large and robust to changes in specification, meaning that firms took account of tax rates when deciding the size of dividends. To get a sense of the magnitudes involved, assume dividends and capital gains are initially taxed at a flat rate of $30 \%$, and that policymakers abolish the dividend tax, while leaving the capital gains tax-rate unaffected. The results here indicate that dividends would increase about $40 \%$.

In accordance with most previous studies, we find the price-drop-to-dividend ratio positively related to dividend-yields, which cannot be explained in this case by tax-induced clienteles among domestic individual investors because, as noted above, dividends and capital gains were taxed at flat rates, separately from ordinary income. This suggests that the observed positive relation was a result of arbitrage-trading among professional institutional investors. We cannot reject the hypothesis that ex-day price-changes were driven by domestic individual investors as the marginal shareholders, but neither can we reject the hypothesis that equally-taxed institutional investors were the marginal shareholders. This result is probably a consequence of the rather small sample size. It would thus be of interest to study this issue using data from other countries that have implemented flat taxes on dividends and capital gains. Finally, as suggested by Bali and Hite (1998) and Frank and Jagannathan (1998), non-tax factors seem to have influenced ex-dividend price-changes during the study period.

Accepted by: Prof. R. Taffler, Guest Editor, February 2008

Prof. P. Theodossiou, Editor-in-Chief, February 2008 


\section{Appendix}

TABLE A1. Correlation Matrix

\begin{tabular}{|c|c|c|c|c|c|c|}
\hline Variable & DIVID & $E X-P R$ & DOR & $M-T O-B$ & $\begin{array}{l}L O G \\
E M P\end{array}$ & $C-F L O W$ \\
\hline DIVIDEND & 1.00 & & & & & \\
\hline EX-PRICE CHANGE & 0.25 & 1.00 & & & & \\
\hline DOR & 0.12 & 0.78 & 1.00 & & & \\
\hline MARKET-TO-BOOK & -0.38 & -0.02 & 0.00 & 1.00 & & \\
\hline LOG EMPLOYMENT & 0.39 & 0.21 & 0.07 & -0.06 & 1.00 & \\
\hline CASH-FLOW & 0.36 & 0.06 & -0.03 & -0.10 & 0.40 & 1.00 \\
\hline EARNINGS & -0.02 & 0.01 & -0.05 & 0.27 & 0.20 & 0.52 \\
\hline FOREIGN SHARE & 0.04 & 0.04 & -0.05 & 0.00 & 0.25 & 0.16 \\
\hline BETA & -0.01 & -0.01 & 0.00 & 0.07 & 0.05 & 0.06 \\
\hline TAX RATIO & -0.06 & -0.06 & 0.03 & 0.03 & -0.06 & 0.02 \\
\hline$O-L I S T$ & -0.24 & -0.11 & -0.05 & 0.00 & -0.54 & -0.26 \\
\hline DIVIDEND YIELD & 0.49 & 0.39 & 0.13 & -0.14 & 0.39 & 0.14 \\
\hline \multirow[t]{2}{*}{$G D P$} & 0.20 & 0.06 & 0.10 & -0.08 & 0.19 & -0.02 \\
\hline & $E A R N$ & FOR SH & BETA & $T A X R$ & $O-L I S T$ & $\begin{array}{c}D I V \\
Y I E L D\end{array}$ \\
\hline EARNINGS & 1.00 & & & & & \\
\hline FOREIGN SHARE & 0.10 & 1.00 & & & & \\
\hline BETA & 0.03 & 0.01 & 1.00 & & & \\
\hline TAX RATIO & 0.16 & 0.09 & 0.01 & 1.00 & & \\
\hline$O-L I S T$ & -0.23 & -0.24 & 0.01 & 0.06 & 1.00 & \\
\hline DIVIDEND YIELD & 0.07 & -0.09 & -0.10 & -0.23 & -0.18 & 1.00 \\
\hline$G D P$ & 0.00 & 0.07 & -0.18 & 0.07 & 0.05 & 0.17 \\
\hline
\end{tabular}

\section{References}

Agell, J.; Englund, P.; and Södersten, J. 1998. Incentives and Redistribution in the Welfare State: The Swedish Tax Reform. Oxford: MacMillian Press.

Ambarish, R.; John, K.; and Williams, J. 1987. Efficient signaling with dividends and investments. Journal of Finance 42: 321-344.

Athanassakos, G., and Fowler, D. 1993. New evidence on the behavior of canadian stock prices in the days surrounding the ex-dividend day. Quarterly Journal of Business and Economics 32: 26-50.

Bali, R., and Hite, G.L. 1998. Ex-dividend day stock price behavior: Discreteness or tax-induced clienteles? Journal of Financial Economics 47: 127-159.

Barclay, M.J. 1987. Dividends, taxes and common stock prices. Journal of Financial Economics 19: 31-44.

Bell, L., and Jenkinson, T. 2002. New evidence of the impact of dividend taxation on the identity of the marginal investor. Journal of Finance 52: 
1321-1345.

Bhattacharya, S. 1979. Imperfect information, dividend policy and 'the bird in the hand' fallacy. Bell Journal of Economics 10: 259-270.

Blouin, J.L.; Raedy, J.S.; and Shackelford, D.A. 2004. Did dividends increase immediately after the 2003 reduction in tax rates? NBER Working Paper No. 10301.

Booth, L. and Johnston, D. 1984. The ex-dividend behavior of Canadian stock prices: Tax changes and clientele effects. Journal of Finance 39: 457-476.

Boyd, J.H. and Jagannathan, R. 1994. Ex-dividend price behavior of common stocks. Review of Financial Studies 7: 711-741.

Bradley, M.; Capozza, D.R; and Seguin, P.J. 1998. Dividend policy and cash-flow uncertainty. Real Estate Economics 26: 555-580.

Brown, J.; Liang, N.; and Weisbenner, S. 2004. Executive financial incentives and payout policy: Firm responses to the 2003 dividend tax cut. NBER Working Paper No. 11002.

Charitou, A. and Vafeas, N. 1998. The association between operating cash-flows and dividend changes: An empirical investigation. Journal of Business, Finance and Accounting 25: 225-249.

Chetty, R. and Saez, E. 2005. Dividend taxes and corporate behavior: Evidence from the 2003 dividend tax cut. Quarterly Journal of Economics 120: 791-833.

Dahlquist, M. and Robertsson, R. 2001. Direct foreign ownership, institutional investors, and firm characteristics. Journal of Financial Economics 59: 413-440.

De Ridder, A. and Södersten, T. 1995. Ex-dividend behavior and the Swedish tax reform. Tax Reform Evaluation Report No. 10. Department of Economics, Uppsala University.

Easterbrook, F. 1984. Two agency-cost explanations of dividends. American Economic Review 74: 650-659.

Elton, E.J. and Gruber, M.J. 1970. Marginal stockholder tax rates and the clientele effect. Review of Economics and Statistics 52: 68-74.

Fama, E. and Babiak, H. 1968. Dividend policy: An empirical analysis. Journal of the American Statistical Association 63: 1132-1161.

Feldstein, M. 1970. Corporate taxation and dividend behavior. Review of Economic Studies 37: 57-72.

Florentsen, B. and Rydqvist, K. 2002. Ex-day behavior when investors and professional traders assume reverse roles: The case of Danish lottery bonds. Journal of Financial Intermediation 11: 152-175.

Frank, M. and Jagannathan, R. 1998. Why do stock prices drop by less than the value of the dividend? Evidence from a country without taxes. Journal of Financial Economics 47: 161-188.

Gaver, J.J. and Gaver, K.M. 1993. Additional evidence on the association between the investment opportunity set and corporate financing, dividend, and compensation policies. Journal of Accounting and Economics 16: 
125-160.

Green, R.C. and Rydqvist, K. 1999. Ex-day behavior with dividend preference and limitations to short-term arbitrage: The case of Swedish lottery bonds. Journal of Financial Economics 53: 145-187.

Jensen, M. and Meckling, W. 1976. Theory of the firm: Managerial behavior, agency costs and capital structure. Journal of Finance 35: 1059-1070.

Kalay, A. 1982. The ex-dividend day behavior of stock prices: A re-examination of the clientele effect. Journal of Finance 37: 1059-1070.

Kalay, A. 1984. The ex-dividend day behavior of stock prices: A re-eximination of the clientele effect: A reply. Journal of Finance 39: 557-561.

Kim, B.S. and Maddala, G.S. 1992. Estimation and specification analysis of models of dividend behavior based on censored panel data. Empirical Economics 17: 111-124.

Lakonishok, J. and Vermaelen, T. 1986. Tax induced trading around ex-dividend days. Journal of Financial Economics 16: 287-319.

Lintner, J. 1956. Distribution of incomes of corporations among dividends, retained earnings, and taxes. American Economic Review 61: 97-113.

McDonald, R. 2001. Cross-border investing with tax arbitrage: The case of German dividend tax credits. Review of Financial Studies 14: 617-657.

Michaely, R. 1991. Ex-dividend stock price behavior : The case of the 1986 tax reform act. Journal of Finance 46: 845-860.

Miller, M.H. and Rock, K. 1985. Dividend policy under asymmetric information. Journal of Finance 40: 1031-1051.

Miller, M.H. and Scholes, M. 1982. Dividends and taxes: Some empirical evidence. Journal of Political Economy 90: 1118-41.

Poterba, J.M. and Summers, L.H. 1984. New evidence that taxes affect the valuation of dividends. Journal of Finance 39: 1397-1415.

Poterba, J.M. and Summers, L.H. 1985. The economic effects of dividend taxation. In E. Altman. and M. Subrahmanyam (eds.). Recent Advances in Corprate Finance. Homewood, IL: Dow Jones-Irwin Publishing, 227-284.

Poterba, J.M. 2004. Taxation and corporate payout policy. American Economic Review 94: 171-75.

Robin, A.J. 1991. The impact of the 1986 tax reform act on ex-dividend day returns. Financial Management 20: 60-70.

Short, H.; Zhang, H; and Keasey, K. 2002. The link between dividend policy and institutional ownership. Journal of Corporate Finance 8: 105-122.

Skinner, D.L. 1993. Twenty-five years of tax law changes and investor response. Journal of Financial Research 16: 61-70.

Wu, C. and Hsu, J. 1996. The impact of the 1986 tax reform on ex-dividend day volume and price behaviour. National Tax Journal 49: 177-192.

Zechhauser, R J. and Pund, J. 1990. Are large shareholders effective monitors? An investigation of share ownership and corporate performance. In R G. Hubbard (ed.). Assymetric Information, Corporate Finance and Investment. University of Chicago Press, 149-180. 